（6）ロゼットパターンは $\mathrm{Al}$ 濃度の增加により種々の形 態を示したが，それらはメルト中の $\mathrm{Al}$ 酸化物が固液界面 によって捕獲された結果として形成されたるのである。ま た，この酸化物の形成によりCu 中の溶存酸素が除去され ることが A1 添加による低転位密度結晶の成長と結びつい ているすのと考光られる。

最後に，本研究の実験に協力された本学学生星野剛一 (現在：神戸製鋼株式会社), 工藤則行 (現在：秋田県警), 渡辺雅二(現在：日本鎘管株式会社)，大浜弘之(現在：日 本䤾管工事秼式会社)，桧森㢣二(現在：日信工業株式会 社) 括よび武田正交(現在：佐佐木メタル工業株式会社)の 諸氏に感謝します。ま, 本研究の一部は文部省科学研究 費の補助の下で行われたことを付記し，あるせて感謝しま के.

\section{文献}

(1) F.W.Young, Jr. and J.R.Savage : J.Appl. Phys., $35(1964), 1917$.

(2) W.A.Tiller : J.Appl.Phys., $29(1958), 611$.

(3) J.Friedel : Dislocations, Pergamon, (1964), 206.

(4) K.A.Jackson : Phil.Mag., 7(1962), 1615.

(5) V.V.Damiano and G.S.Tint : Acta Met., 9(1961), 177 .
(6) M.D.Hunt, J.A.Spittle and R.W.Smith : J. Crystal Growth, 3, 4(1968), 656.

(7) A.J.Goss, K.E.Benson and W.G.Pfann : Acta Met., 4 (1956), 332 .

(8) W.Bardslay, J.B.Mullin and D.T.J.Hurle : The Solidification of Metals, The Iron and Steel Inst., (1968), 93.

(9) P.G.Deo and S.D.Sharma : Phil. Mag., $10(1964)$, 423.

(10) K.R.Evans and W.F.Flanagan : Phil. Mag., 14 (1966), 1131.

(11) J.Watanabé, Y.Imashimizu, H.Nagumo and $K$. Tsukamoto : J.Crystal Growth, 24/25(1974), 414.

(12) D.Jaffrey and G.A.Chadwick : Phil. Mag., 18 (1968), 573.

(13) 山本美喜雄, 渡辺慈朗 : 結晶工学ハンドブック，共 立出版，(1971)，388.

(14) F.W.Young, Jr. : J.Appl. Phys., 32(1961), 192.

(15) K.Marukawa: J.Appl.Phys.Japan, 6 (1967), 944.

（16）井上哲夫，渡辺慈朗，三浦恒雄，山本美喜雄：日本 金属学会誌, 36(1972), 256;'Trans.JIM,14 (1973), 285.

(17) J.D. Livingston : Direct Observation of Imperfections in Crystals, Interscience Pub., (1962), 115.

(18) W.A.Tiller, K.A.Jackson, J.W.Rutter and B. Chalmers : Acta Met., 1 (1953), 428.

(19) R.M.Sharp and A.Hellawell : J.Crystal Growth, $11(1971), 77$.

\title{
急冷 $\mathrm{Cu}$ 結晶 $(111)$ 面におけるエッチビークの形成について*
}

\section{菅 原 茂 夫** 渡 辺 慈 朗*}

J.Japan Inst. Metals, Vol.45, No.10(1981),pp. 996 1002

On the Formation of Etch Beaks on the (111) Surfaces of Rapidly-

Cooled Copper Crystals

Shigeo Sugawara** and Jirô Watanabé**

The (111) surfaces of copper crystals rapidly-cooled from $1273 \mathrm{~K}$ in a purified Ar atmosphere were etched in three kinds of dislocation etchants, and the etch patterns were studied by means of optical and electron microscopies. From the replica examinations with an optical microscope dark and deep etch pits with beaks were found in addition to the normal dislocation etch pits. Their densities amounted to $10^{7}-10^{8} \mathrm{~m}^{-2}$, two orders of magnitude less than those of the normal ones. When the crystal was etched for a long period, the etch pits with beaks gradually changed from sharply-pointed and deep ones to flat-bottomed and shallow ones, and finally disappeared, while small ones newly appared at some other places. It is noted that such etch pits cannot be observed in copper crystals slowly-cooled from the same temperature in Ar atmosphere. Detailed observations of the replicas with an electron microscope revealed that the beaks extended into the inside of the crystal from the apex of the etch pits along the oblique [110] (otherwise [101] or [011]) direction though details of their shapes varied with changing etching solution. Defect ribbons with a somewhat complicated structure were observed in thin films obtained from the rapidly-cooled copper crystal, which might presumably be associated with the etch beaks.

(Received April 6, 1981) 


\section{I. 緒言}

結晶を適当な熱的あるいは化学的条件下で腐食すると， 低指数結晶面に規則的な形状をるったエッチピットが形成 される。エッチピットは腐食によって結晶小面が現出する 結果として形成されるすのであり, 現出される小面の配置 は当該結晶表面の対称性に対応するから，それによって構 成されるエッチピットの梘則形状るまたと礼々同一対称性 を示すのがふつらで市る。しかしながら，その上らな規則 性を示さないエッチピットの存在も古くから知られてお り，それらは異常エッチピットと呼ばれている(1). 異常エ ッチピットにはいくつかの型があるが，その中でエッチピ ットの底部から結晶内部に組い柱状の孔がくちばし状につ き出ているすのをビークといい、(1) (3)，文の伸びる方向が でたらめなるのは上述の規則性と合致しない。

ビークが結唱の格子欠陷位置に形成されることを示した のは1958年の Lovel1(4) の報告が最初のものであ万ら、彼 女は燐灰石の(0001) 面を酒石酸 (333〜343 K) あるいはクェ ン酸 $(333 \sim 343 \mathrm{~K})$ によって腐食して，六角形のエッチピッ トの底部を垂直に貫くビークとでたらめな方向に斜めに伸 びるビークが形成されることを観察した，そして，前者に ついてはそれが覀境界配列をとることから状転位に対応 することを報告している，後者については 1964 年になっ て Fleischer ら ${ }^{(5)}$ とよって燐厕石中に不純物として含季れ るウランなどの放射性元素の地質学的年代にわたる核分裂 破片の飛跡汇対応することが示された，艺の上らなビーク

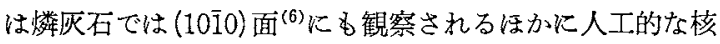
分裂源にさらした橉死石や雲母結晶の腐食に打いてる形成 される(5).ビークと類似したものにウィングとよばれるす のがある。こ机はエッチピットの側方につばさ状のくばみ をるつものであるが，亜セレン酸塩結晶のウィングあ核分 裂破片の飛跡によるといわれている(7).

また，長鎖脂肪酸の水溶液によって腐食された $\mathrm{LiF}$ 結 唱 ${ }^{(8)(9)}, \mathrm{CdCl}_{2}$ と $\mathrm{NaCl}$ を含むメタノールによって腐食さ れた $\mathrm{NaCl}$ 結晶 ${ }^{(10)}$ 和上び濃フッ酸厄よって腐食された水 晶(11)に拈いてもビークが観察されて和り，それらはいず れる転位に起因することが示されている。ただ，LiF 結晶 ではらせん転位によるが， $\mathrm{NaCl}$ 結晶では不純物が偏析し た刃状転位に対応し，しかも去の形成には腐食液の不飽和 度とポイズン $\left(\mathrm{CdCl}_{2}\right)$ 濃度が影響する(10)。水晶ではふつう の転位のほかにつるまき転位の位置にも形成される(11). $\mathrm{Si}$ 結晶の不純物火よってデコレートされた汾曲する転位 䌨にビークが形成される可能性も指摘されている(3).

今回，われわれは高温で烧鈍後急冷した Cu 結晶 (111)

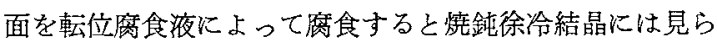
れないビークをるつエッチピットが転位ピットのはが形 成されることを見出したので報告する。

\section{II. 実 験 方 法}

本研究に战いて用いた $\mathrm{Cu}$ 単結晶虹再電解銅 $(99.998 \%)$ を素材とし，純化 Ar ガス䨌囲気中でチョクラルスキー法 により [111]方位に育成した直径 8〜 10 $\mathrm{mm}$ の丸棒状結晶 である。まず，光像法 ${ }^{\{12\}}$ により棒軸に注济垂直な(111) 面 の方位を $8.73 \times 10^{-3} \mathrm{rad}\left(0.5^{\circ}\right)$ 以内で決定し，酸切断を行 らことにより(111) 面を端面とする高さ〜10 mm の円柱試 料を得た。つぎに，この試料を高純度黑鉛ボートにのせて 焼鈍炬に入れ，純化 $\operatorname{Ar}\left(\mathrm{O}_{2}\right.$ 和よび $\mathrm{N}_{2}<0.1 \mathrm{ppm}$, 露点 $<200$ K)を流しながら $1273 \mathrm{~K} て ゙ 7.2 \times 10^{3} \mathrm{~s}(2 \mathrm{~h})$ 牧錰したのら， 黒鉛ボートごと試料苦灯芯管内の炬外 $19 \mathrm{~cm}$ の位置(温度 〜320 K)にすみやかに引出すことにより急冷した。采た， これと同温度同時間焼鈍したのち〜 $7 \times 10^{-2} \mathrm{~K} / \mathrm{s}$ の速度で 徐冷した $\mathrm{Cu}$ 結晶も用意した。

これらの試料銅製の円筒ホルダー内に(111) 表面が露 出するよらにパラフィンを用いて埋込んだのち，塩化第 2 銅飽和塩酸で妨したらしゃ布上を軽くすべらせるよらに して研摩した。（111)表面が平滑になったらパラフィンを 溶融してホルダー上り試料をとり出し，有機溶剂をつかっ て試料表面のパラフィンを除去したのち，濃燐酸液中に拧 いて電圧 $1.5 \mathrm{~V}$ で数時間電解研摩を行った，办洗後蒸留 水 $(285 \mathrm{~K})$ 中におよ艺 $1.2 \times 10^{2} \mathrm{~s}(2 \mathrm{~min})$ 保持したのち，直

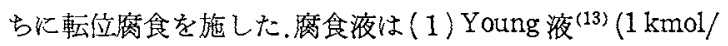
$\left.\mathrm{m}^{3}\left(\mathrm{NH}_{4}\right)_{2} \mathrm{~S}_{2} \mathrm{O}_{8}, 6 \mathrm{kmol} / \mathrm{m}^{3} \mathrm{NH}_{4} \mathrm{OH}, 0.3 \mathrm{kmol} / \mathrm{m}^{3} \mathrm{NH}_{4} \mathrm{Br}\right)$, (2) 丸川液 ${ }^{(14)}\left(\mathrm{FeCl}_{3} \cdot 6 \mathrm{H}_{2} \mathrm{O} 50 \mathrm{~g}+\mathrm{H}_{2} \mathrm{O} 103 \mathrm{~cm}^{3}+\mathrm{HCl} 80 \mathrm{~cm}^{3}\right.$ $\left.+\mathrm{HBr} 3 \mathrm{~cm}^{3}\right)$ 括よび (3) Livingston 液 ${ }^{(15)}\left(\mathrm{HCl} 25 \mathrm{~cm}^{3}+\right.$ $\mathrm{CH}_{3} \mathrm{COOH} 15 \mathrm{~cm}^{3}+\mathrm{H}_{2} \mathrm{O} 90 \mathrm{~cm}^{3}+\mathrm{Br}_{2} 1 \mathrm{~cm}^{3}$ ) であり, 恒温槽 によって $285 \mathrm{~K}$ の温度に保持してそれぞれ 5 〜30 S の適当 時間腐食した，陚料を水洗，風乾したの方，(111) 表面に 形成されたエッチピットを直接あるいはレプリカを作製し 光顕観察を行った。光顕観察用レプリカはまずェッチピッ トをプラスチックフィルム(Bioden テープ)にうつしとり, これに 0.105 0.140 $\mathrm{rad}\left(6^{\circ} \sim 8^{\circ}\right)$ の方向加 Ag を蒸着す ることによって影付けしたものである。ささらに，エッチピ ットの微細構造を調べるために電顕レプリカ観察(日本電 子、 JEM-200A)を行ったが、そのためにはPt-20\%Pdシャ ドー・カーボンレプリカを作製して観察に供した。 なお，

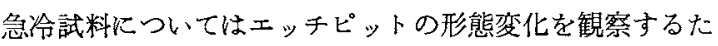
めさらに電解研摩を $120 \mathrm{~s}$ 行ったのち, 適当な液による適 当時間の腐食を行らといら手続きを1〜2回繰返した。

\section{III. 実 験 結 果}

\section{Young 液 ${ }^{(13)}$ による腐食}

急冷拈よび徐冷 Cu 結晶 (111) 面を Young 液 ${ }^{(13)}$ Kよっ て $5 \mathrm{~s}$ 腐食することによって得られたエッチピットの典型 的な光影レプリカ写真をPhoto.1 亿示した。すなおち，両 者の腐食表面には三角錐の黑ピット，白ピットおよびそれ 
らが芘合した黒白ピットが形成されていることがわかる。 ただ，急冷結晶 (Photo.1(a))のピットの中には黒好で囲ん だ部分に見られるよらに、シャドーイングによる影が著し く長い黒ピットが存在するに対し, 徐冷結晶 (Photo.1(b)) にはそのようなものは全く見られない。急冷結晶の長い影 をもつピットの密度は $10^{7} \sim 10^{8} \mathrm{~m}^{-2}$ であり，らつ5の転 位ピットの密度 $10^{9} \sim 10^{10} \mathrm{~m}^{\text {一2 }}$ よりるずっと少ない.

つぎに，急冷結晶の影の長いピットの構造を電顕レプり

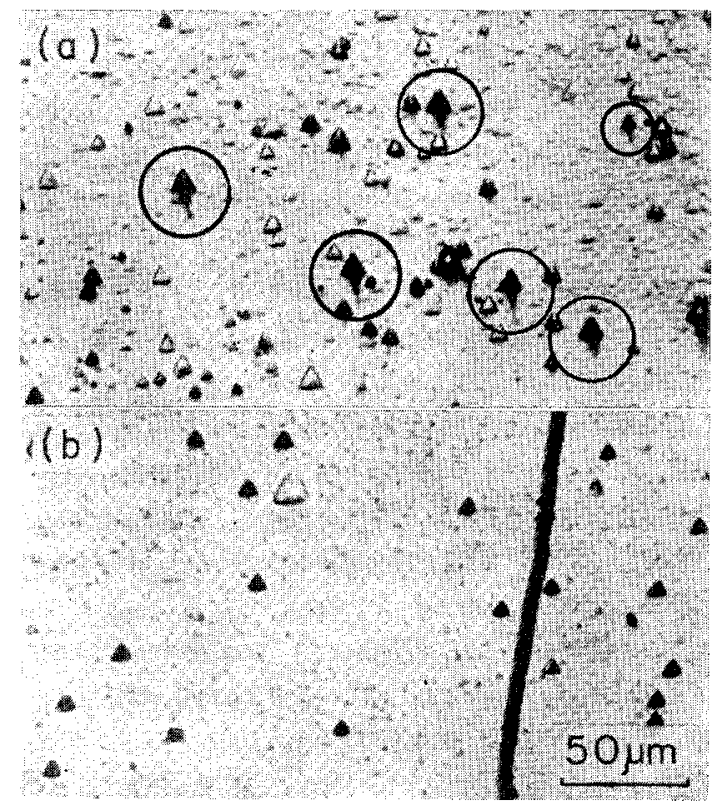

Photo.1 Replica optical micrographs of etch pits formed on the (111) surfaces of $\mathrm{Cu}$ crystals after etched with Young's etchant(13) for $5 \mathrm{~s}$.

(a) Repidly-cooled from $1273 \mathrm{~K}$,

(b) Slowly-cooled.
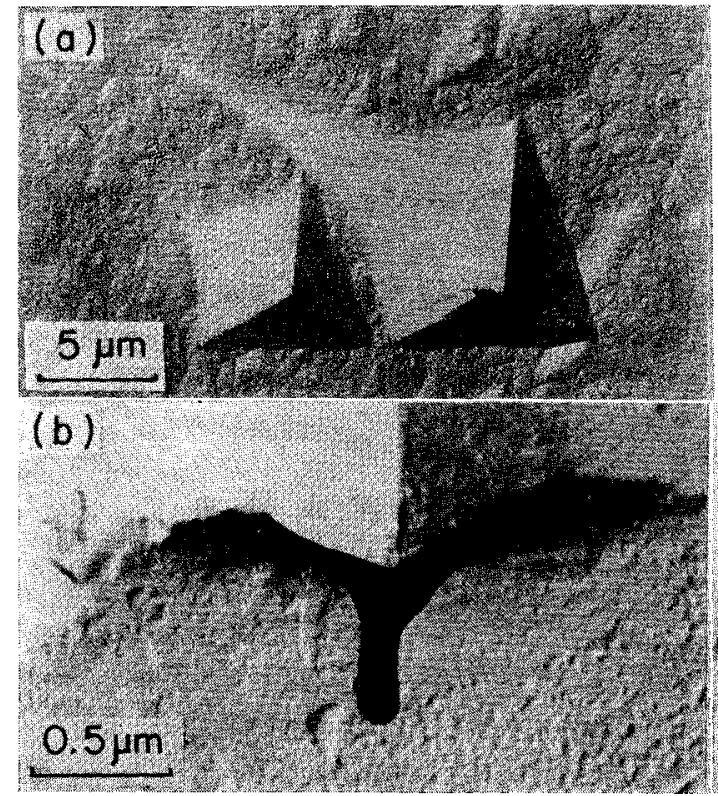

カ観察によって調べた結果をPhoto.2に示した. Photo. 2 (a)に見られる 2 個のピットのらら, 左側のものはほぼ三 角錐をなすらつうの転位ピットであり，その影の長さとシ +ドーイング角度から求めら礼た側面傾斜は〜0.23 rad $\left(\sim 13^{\circ}\right)$ であって，光顕観察に括ける黒ピットに対応す る(16)(17).な积，白ピットは傾面傾斜は黒ピットよりるゆ るやかで $0.10 \mathrm{rad}\left(6^{\circ}\right)$ 以下である(16)(17). これに詨して， Photo.2(a)の右側のエッチピットはその影の長さと形から 左側の黑ピットよりる側面傾斜がかなり大きいこと, 単純 な三角錐でないこと和よび最先端部に特有の構造をるって いることがわかる。側面傾斜はピットの上部では〜0.31 $\operatorname{rad}\left(\sim 18^{\circ}\right)$ で比較的ゆるやかであるが，中間部より急に傾 斜を增し先頭部では〜0.70 rad $\left(\sim 40^{\circ}\right)$ の傾斜をなす。こ のエッチピットの最先端部を高倍率で観察したのが Photo. 2(b)である、すなわち，エッチピットの先端には細長い円 柱状の突起すなわちビークが形成されており，それは三角 錐の側面どうしがつくる棱の延長線の方向に折れ曲がって 煔り，ピットの先端より結晶中に斜めに伸びていることが わかる. Photo.2(c)は傾斜装置を用いてレプリカを傾ける ことによって皃どークに沼う力向から高倍率で観察した 写真である。これよりどークは前述のょうに細いく 0.1 $\mu \mathrm{m}$ 径)円柱をなし，しかもそれが突きでているピットの 先端部はほぼ四角錐をなしていることがわかる、また，こ のときのレプリカの傾斜角度は装置が許す最大角度 $\pi / 6$ $\left(30^{\circ}\right)$ であったがその傾斜方向は[110]方向([111]/[110]= $\pi / 5.1\left(35^{\circ} 16^{\prime}\right)$ kほぼ一致して和り，ビークはほぼ[110]方 向に沿って伸びていると考えられる．同様にして多くのピ ットのビークの方を調べた結果，そ礼らは [110]，[101] および［011]方向のいずれかの一つに一致することがわか った。

Photo.2 Replica electron micrographs of etch pits formed on the (111) surface of a rapidly-cooled $\mathrm{Cu}$ crystal after etched with Young's etchant ${ }^{(13)}$ for $5 \mathrm{~s}$. (a) Dark pit with beak (right), (b) Enlarged top view of an etch pit with beak, (c) Enlarged top view nearly along the beak.

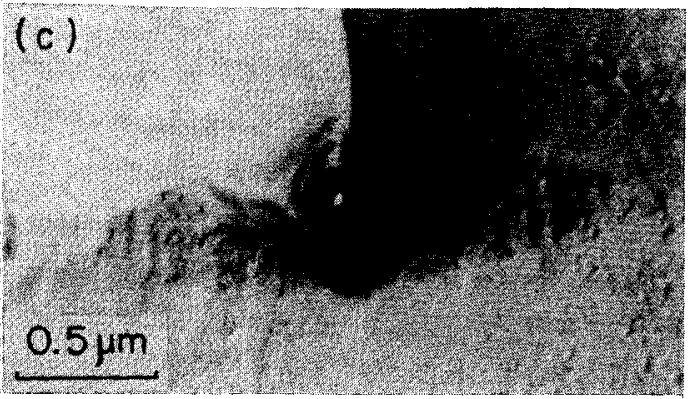


つぎにこのよらなビークをもつエッチピットが鹰食の継 続によってどのよらに変化するかを調べた. Photo.3に Young 液 $20 \mathrm{~s}$ 腐食の光顕レプリカ写真を示した. Photo. 1 (a) との比較から分るように，長い影のピットはすべてが 小さな黒ピットとして観察されたが，20s 腐食ではそのよ らなピットの福が長い影のついた大きな黒ピットと黒 白ピットがあらわれた。このうち，大きな黑ピットは短時 間腐食の小さな黑ピットが成長したものであり，むた黒白 ピットはその影の形状より判断して先頭部は平坦もしくは それに近い形状をなして扣り，それらはエッチビークの形 成の源が結晶内部に拈いて消失したために，頭部が腐食の 進行ととるに平坦化して黒白ピットを形成するにいたった ものと考えることができる。このよらた影の長い黑ピット は腐食時間をますと寸法が大きくなり，さらに黒白ピット に変化する過程は Young 液 $5 \mathrm{~s}$ 腐食と光顕観察の数度の 繰返しの実験によっても確められて岕り，このことはエッ チ・ビーク形成の源は結晶内部に比較的短距離にわたって 伸びる欠宿であることを示している。なお，Cu 結晶 (111) 面に出現点をるつ正和よび真の刃状転位はふつう Young 液によってそれぞれ黑ピット㧍よび白ピットとして現われ るが(13)〈(16)(17)，上述のよらにビークをるつェッチピットは それらとは全く異なる形状をしており，それはく110〉方 向に伸びるふつらの転位とは異なる短い欠宿に対応するも のと考光られる.

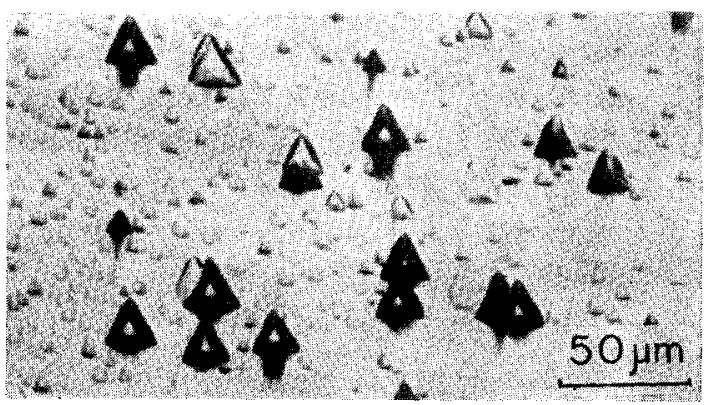

Photo.3 Replica optical micrograph of etch pits formed on the (111) surface of a rapidly-cooled $\mathrm{Cu}$ crystal after etched with Young's etchant(13) for $20 \mathrm{~s}$.

\section{2. 丸川液 ${ }^{(14)}$ による腐食}

受冷 $\mathrm{Cu}$ 結晶 (111) 面を丸川液によって7 $\mathrm{s}$ 腐食すること により形成されたエッチピットの光影レプリカ写真を Photo.4に示した。この場合にも，ふつらの黒ピット，白 ピットおよび黑白ビットのほかに長い影をもつ黑ピット (写真円内) が形成されている。丸川液による腐食後ひき続 いて軽く電解研摩してYoung 液により $5 \mathrm{~s}$ 腐食して光顕 レプリカ観察を試み，両者の影の長い黑ピットに対応性が あることを確認した，丸川液7 $\mathrm{s}$ 腐食に拈ける長い影をも つ黒ピットを電顕レプリカ観察したのが Photo.5である. まず，Photo.5(a)よりわかるよらに丸川液による長い影を るつェッチピットは傎斜が浅くから丸味を和びて就り，影
の長さとシャドーイングの角度から求められた三角錐の側 面傾斜はふつらの黒ピットのそれとほぼ同じ〜0.14 rad (80)であり，去の先端から突出したビークが細長い影を作 っている。このビークの部分を高倍率で観察したのが Photo.5(b)であり，また傾斜装置を用いてレプリカをとれ が許す最大の角度 $\pi / 6\left(30^{\circ}\right)$ 傾 斜することによって汪ばビ 一クに沿ら方向から観察した写真がPhoto.5(c) である.ビ 一クは三角錐の側面がつくる稜の延長線の方向に折れ曲が って拉り，Young 液の場合と一致してビークの伸びる方 向は[110](あるいは[101],[011])方向に一致していると考 えられる、ただ，Young 液の場合にはビークははぼ柱 状をなしていたが(Photo.2(c)参照)，丸川液のビークは平 たい四角柱をなしている。これはPhoto.5(a)にみられる 平坦な小面の現出から推定されるよらに，丸儿液は(111)， (100) あるいは(110)面のような稠密面を現出する性質をも っているために，四角柱のどークが形成されたものである 5 .

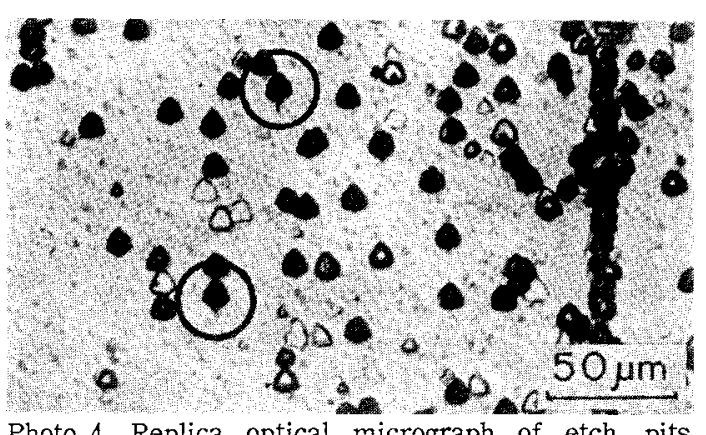

Photo.4 Replica optical micrograph of etch pits formed on the (111) surface of a rapidly-cooled $\mathrm{Cu}$ crystal after etched with Marukawa's etchant(14) for $7 \mathrm{~s}$.

また，Photo. 2 と Photo. 5 との比較からわかるよ5に， 両者のビークをもつピットの 2 次元寸法はほぼ同じである が，深さは前者の方が虑食時間が短いにすかかからずずっ と大さい。これはYoung 液の方が丸川液よりもどークを あらわす欠陷に沿ら方向の溶解が顕著であることを示する のである。な拉，さきに述べたように丸川液による腐食に 扣いてふつらに見られる $\mathrm{Cu}(111)$ 面の黒ピットはらせん転 位に対底するが，上記の影の長い黑ピットはその性状から らせん転位とは異なる欠陥に起因するものと結論される。

\section{Livingston 液 ${ }^{(15)}$ による腐食}

この液によるCu結晶(111)面の腐食はらつう正および 負の羽状転位位置にそれぞれ黑执よび白ピットを形成する ことが知られている(15). 急冷 $\mathrm{Cu}$ 結晶をこの液により 30 s腐食したときの光顕レプリカ写真をPhoto.6に，ま たその中にみられる影の長い黑ピットの電影レプリカ写真 をPhoto.7に示した。これらの写真から知られるよらに， Livingston 液によるビークをもつ黑ピットの形状は丸川 液のをれと類似して物り，比較的ゆるやかな傾斜( 0.17 $\left.\operatorname{rad}\left(10^{\circ}\right)\right)$ をる傾面からなる妹をを和びた三角錐の先端 

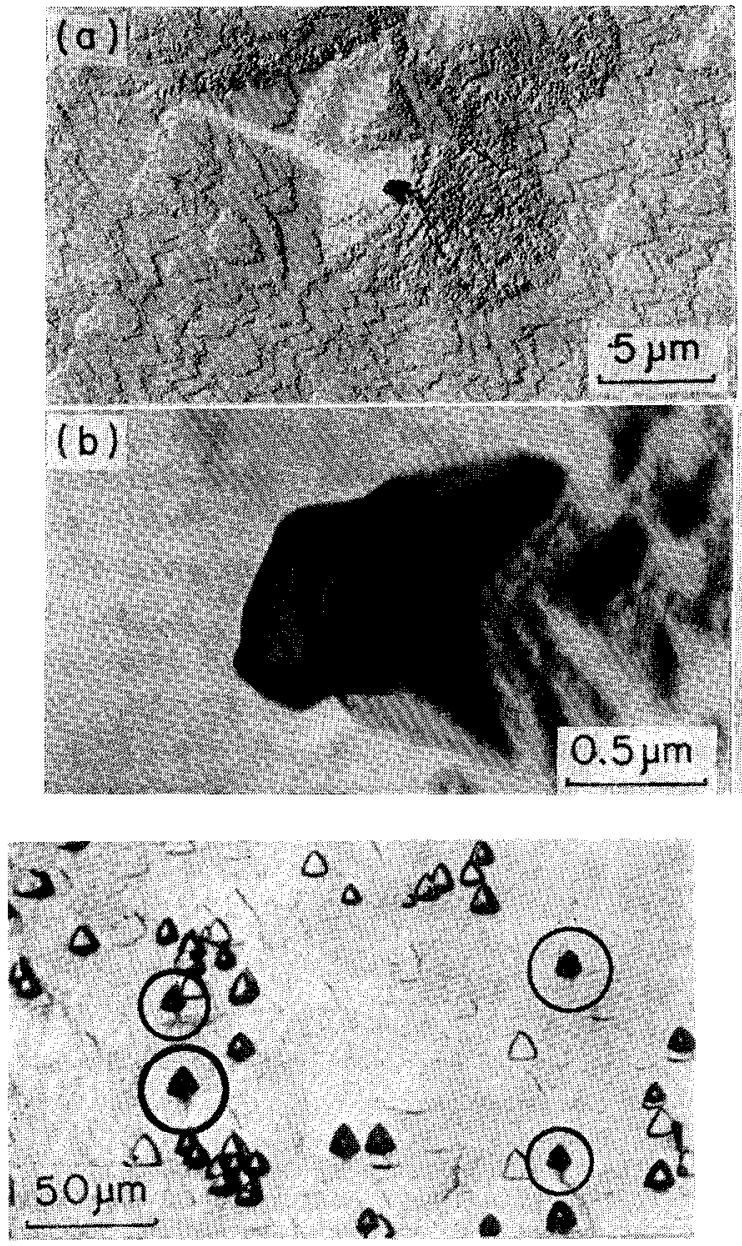

Photo.6 Replica optical micrograph of etch pits formed on the (111) surface of a rapidly-cooled $\mathrm{Cu}$ crystal after etched with Livingston's etchant(15) for $30 \mathrm{~s}$.

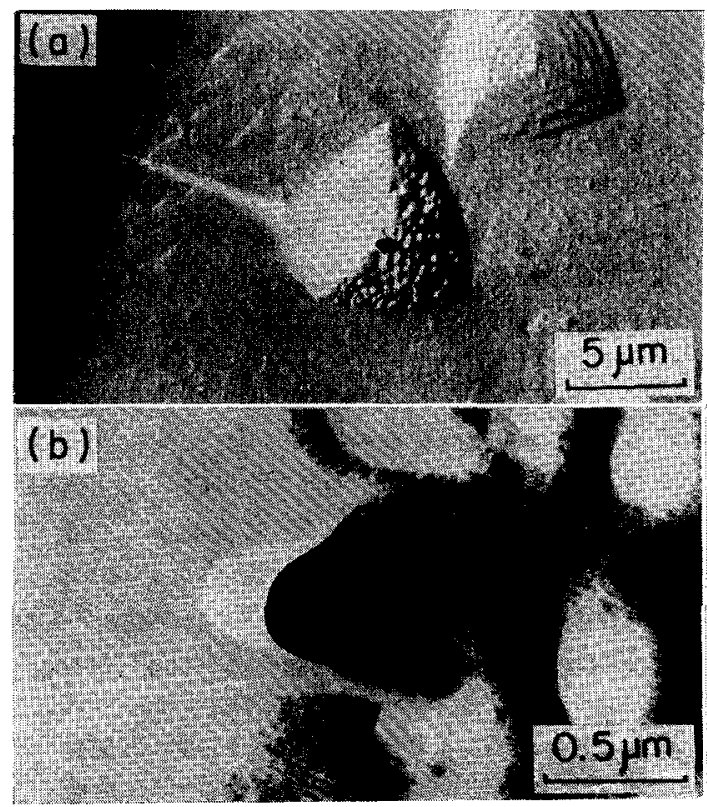

Photo.5 Replica electron micrographs of an etch pit with beak formed on the (111) surface of a rapidlycooled $\mathrm{Cu}$ crystal after etched with Marukawa's etchant(14) for $7 \mathrm{~s}$.

(a) Dark pit with beak, (b) Enlarged top view of an etch pit with beak, (c) Enlarged top view nearly along the beak.

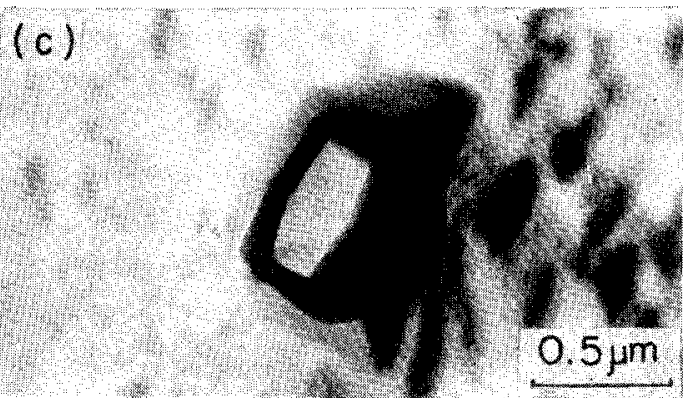

から丸味をおびた四角柱のビークが[110](㘯るいは[101]， [011]）方向に沿って伸びている。

$$
\text { IV. 考察 }
$$

以上のように， $\mathrm{Cu}$ 結晶を $\mathrm{Ar}$ 雾囲剧中に括いて $1273 \mathrm{~K}$ ， $7.2 \times 10^{3} \mathrm{~s}(2 \mathrm{~h})$ 焼鈍後，炉の低温部 $(2320 \mathrm{~K})$ 飞引きだす ことによって急冷し，(111)面を転位腐食液によって腐食 すると，ふつうの転位ピットのほがビークをるつエッチ ピットが形成される。このエッチピットは(1)同盜度で同 時間焼鈍後 $7 \times 10^{-2} \mathrm{~K} / \mathrm{s}$ の速度で徐冷した (111) 面には現 わ枕い（2)腐食の進行とともにピットの寸法は大きく なるが，同時に形状む変化して浅くなりやがて消隇する。

Photo.7 Replica electron micrographs of an etch pit with beak formed on the (111) surface of a rapidlycooled Cu crystal after etched with Livingston's etchant ${ }^{(15)}$ for $30 \mathrm{~s}$.

(a) Dark pit with beak, (b) Enlarged top view of an etch pit with beak, (c) Enlarged top view nearly along the beak.

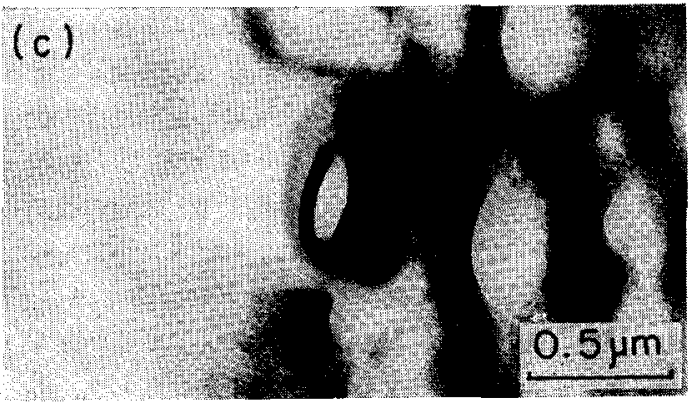


(3)エッチピットの形状は腐食液によって異なるが，その 先端のビークは[110],[101]あるいは[011]方向に沿って結 晶中に斜方向に伸びていることがわかった，

これまでに，二，三の鉱物結晶招よびイオン結晶につい て調べられた結果によると，ビークをるつエッチピットは 転位位置あるいは不純物として含まれる放射性元素の核分 裂破片の飛跡位置に形成される(4)〜(11)．これに対して Cu 結晶において見られたビークをるつェッチピットは同時に 形成されるふつうの転位ピットと全く性状を異にして和 り，単純な転位に起因するるのでないことは明らかであ る. Hari Babu 拉よび Bansigir ${ }^{(10)}$ は焼鈍徐冷した $\mathrm{NaCl}$ 結晶を転位腐食すると，ビークをるつエッチピットが形成 されるのに対し，変形した結唱には形成されないといら実 験事実から不純物が偏析した刃状転位がその源であるとし た，そして，その不純物原子が母結晶の原子よりあはやく 溶けだすため，西るい忶転位線近傍の表面エネルギーをひ くめるために転位線に沿ら溶解が促進される結果としてビ 一クが形成されると結論している。しかしながら，上述の Cu結晶のビークはそのような転位に対応しないし，また 二，三の鉱物結晶に和いて見出されている核分裂破片の飛 跡炕も対応しないことは明らかである。本研究に䗋いて見 出されたビーク性急冷結晶に特有のしかも<110>方向に 沿う比較的短い欠陷に対応すると考えることができる.

Barnes 括よび Mazey ${ }^{(18)}$ は高純度 $\mathrm{Cu}$ 薄片 (Johnson Matthey 分光標準，厚さ $0.05 \mathrm{~mm}$ )を $\mathrm{Ar}$ 雾囲気中で 1328 $\mathrm{K}, 300 \mathrm{~s}$ (5 min) 焼鈍したのち $294 \mathrm{~K}$ の轻中汇焼入れ，そ れより薄膜を作製して透過電顕により観察した。彼らによ 凡ば結晶中には平均直径 $2 \times 10^{-8} \mathrm{~m}$ の析出物が多数（１.5 $\left.\times 10^{12} \mathrm{~m}^{-2}\right)$ 形成され，そ机を中心にして<110>方向に格
子間型のプリズマティック転位ループ列が形成される。そ して，それらは真空中焼入れでは形成されないことから $\mathrm{Ar}$ 中の不純物が $\mathrm{Cu}$ 中に析出物をつくることに原因して いると結論された。このはかに，急冷 $\mathrm{Cu}$ 結晶中には凍結 点欠宿他起因する皘層欠陷 4 面体，積層欠陥を含む転位少 一プなどの種々の2 次欠陷の形成も知られて括り(19)(20)， 積層欠宿の形成は酸化と関係しているとの報告 ${ }^{(21)}$ ある。

しかしながら，本実験に乱壮るCu 結晶の条件は上述の

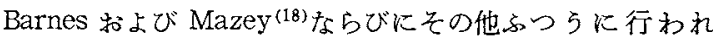
ている実験とは相違している。そこで，急冷試料からェッ チピット観察を行った(111) 面物よびそれに垂直な(110)お よび $(2 \overline{1} \overline{1})$ 面をそれぞれ膜面とする薄膜を酸切断 $\rightarrow$ 化学研 摩一粗電解研摩 て作製 $L$ ，透過電顕(日本電子，JEM-200 A) 観察を行。 た。その結果，すべての薄膜に無秩序に分布するボイド， 転位执よび転位ループが容易に観察され，このほかにそれ よりも少頻度ではあったが細長いリボン状の欠陷が見られ た. Photo.8飞比較的よく観察された (110) 薄膜のリボン 状欠宿を示した。この欠陷住 [110]方向に走行し，大きい ものでは幅 $0.3 \mu \mathrm{m} \times$ 長さ $15 \mu \mathrm{m}$ の寸法をもって和り，黒 白の帯の縞模様を形成している(Photo.8(a))。そして, 黒 い帯の部分は拡大像 (Photo.8(b))を見るとわかるように， 積層欠陷，双晶あるいは析出物などに特有の干涉縞からな る。このりボン状欠陷は膜面方位と形態护よび観察頻度か ら\{111\}面内炕ることが推測され，さらにとの性状を二， 三調べてみた。

まず，リボン状欠陷とくに黒い帯を含む部分とその近傍 の基地の制限視野回折像を(種々の傾斜角度において) 調べ

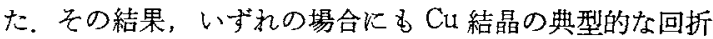

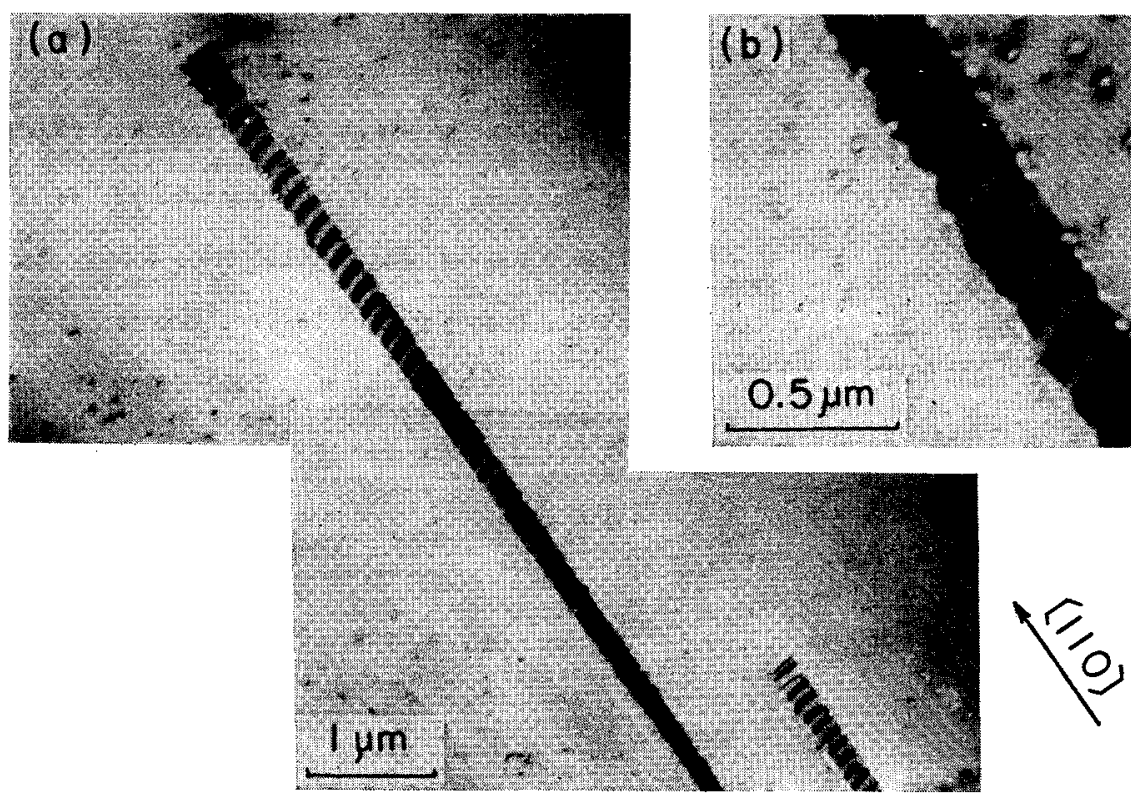

Photo. 8 Transmission electron micrographs of a (110) foil prepared from a rapidly-cooled $\mathrm{Cu}$ crystal. (a) Defect ribbons, (b) Enlarged view. 
像がみられ，2 重回折などによる余分な斑点もみられなか った。このことは当該欠宿が析出物あるいは双晶である可 能性は小さいことを示す。つぎに，リボンの走行方向に垂 直な方向の強度分布は明視野で対称, 暗視野 (反射べクト ル $g=111,002,11 \overline{1}, 220)$ で非対称であり，黑い帯の部分 の縞は双晶ではなく，積層欠陥である可能性 ${ }^{(22) か ゙ ส さ れ ~}$ た，そこで，つぎに黒い带の端部に批る部分転位の確認 を試みた，リボンの中の久陷は多くの場合観察中に [110]

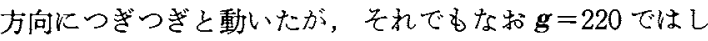
ばしば転位線が観察されたに対し，その他の反射 $(\mathbf{g}=111$ ， 002，11立)では観察できず，転位の性格を决定することはで きなかった。しかし，それぞれの黒い帯の端部に転位が存 在していることが確認され，結局これらの観察結果よりり ボン状欠陷は積層欠陷をはさんだ拉癷転位列である可能性 が高い。しかし，詳細にみると(Photo.8(b)) 白の帯の中に もほぼ垂直に貫めく縞が存在し，単純な転位列だけからな る構造でないるうである。また，そのへりにはボイドが一 列に並んでいるものもいくつか観察された(例えば Photo. 8(b)). 縞のコントラストが消克る反射べクトルを用いて 欠陷内部のボイドの有無を謂べたが，内部にはボイドは認 あられなかった。へりにボイドをるたないリボン状欠陷る 多く存在することをあわ世考劣ると，黑い带のへりに存在 するボイド列は急冷中になんらかの理由によって集積した ものであろう。

いまのところ，上記のリボン状欠宿の形成機構は不明で あり，またそれがビークの形成源であることの直接的な証 扰はない、しかしこの欠陷は結晶内部に比較的短い距離 をるってく110>方向に伸びているといら点に乱いて前述 の実験事実 (2)扣よび (3)を説明できる欠陷であり，ビー クの源であると推定される。

\section{V. 総 括}

Ar 雲囲気中で $1273 \mathrm{~K}, 7.2 \times 10^{3} \mathrm{~s}(2 \mathrm{~h})$ 焼鈍後，炉の低 温部に引き出すことによって急冷した $\mathrm{Cu}$ 結晶の(111) 面 を3種の転位腐食液 ${ }^{(13) \sim(15)}$ によって腐食し，光顕および 電顕観察を行い, $10^{9} \sim 10^{10} \mathrm{~m}^{-2}$ の密度の転位ピットのほ かに $10^{7} \sim 10^{8} \mathrm{~m}^{-2}$ の密度のビークをもつ深いエッチピッ トが形成されることを見出し，ての性状を調べた。得られ た結果は次の通りである。

(1) $1273 \mathrm{~K}, 7.2 \times 10^{3} \mathrm{~s}(2 \mathrm{~h})$ 焼鈍後 $7 \times 10^{-2} \mathrm{~K} / \mathrm{s}$ の速 度で徐冷した Cu結晶(111)面にはビークをもつエッチピ ットは全く見られず，急冷結晶特有のるのである。

（2）ビークをもつピットは腐食の進行とともに寸法が大 きくなるととすにやがて底の平らなピットに変化しついに
は消滅するが，同時に新しいビークをもつピットがあらわ れる。

(3)どークをもつエッチピットの形状は腐食液の種類に よって異なるが，いずれの液に叔ててビークはエッチピ ットの先端から結晶中にく110〉方向に海って斜めに伸び ている

（4）急冷結晶より作製した薄膜の透過電顕観察により， 幾分複雑な構造をるくく110>方向に走行するリボン状 久楩が観察された。それの形成過程については不明である が，上記のビークの形成源と推定された。

最後に，本研究の実験の一部に協力された料池勝三氏に 感謝します。

\section{文献}

(1) A.P.Hones : The Nature, Origin and Interpretation of the Etch Figures on Crystals, John Wiley and Sons Inc., New York, (1927), 43.

(2) H.E.Buckley : Crystal Growth, John Wiley and Sons Inc, New York, (1951), 304.

(3) W.G.Johnston : Progress in Ceramic Science, volII, Pergamon Press, (1961), 34.

(4) L.C.Lovel1 : Acta Met., 6(1958), 775.

(5) R. L. Fleischer, P. B. Price and E. M. Symes : Amer. Mineral., 49(1964), 794.

(6) A. R. Patel, M. K. Agarwal and C. C. Desai : J. Phys. Soc. Japan, 23(1967), 553.

(7) A.R.Patel and K.K.Raju : Acta Cryst., 23 (1967), 217

(8) A. R. C. Westwood, H. Opperhauser and D. L. Goldheim : I.Appl. Phys., 33 (1962), 1764.

(9) A.R.C.Westwood and H.Rubin : J.Appl. Phys., $33(1962), 2001$.

(10) V.Hari Babu and K.G.Bansigir : J. Appl. Phys., $40(1969), 827$.

(11) T.Hanju : J.Phys. Soc. Japan, 19(1964), 1489.

（12）山本美喜雄，渡辺慈朗：金属物理実験室, アグネ， (1964), 34.

(13) F.W. Young, Jr. : J.Appl. Phys., 32(1961), 192.

(14) K. Marukawa : Japanese J.Appl. Phys., 6(1967) 944.

(15) J.D.Livingston : Direct Observation of Imperfections in Crystals, Interscience Pub., (1962), 115.

(16) 渡辺慈朗, 菅原茂夫：日本金属学会誌, 41 (1977), 612

(17) J.Watanabé and S.Sugawara : Trans. JIM, 19 (1978), 511.

(18) B.S.Barnes and D.J. Mazey : Acta Met.,11 (1963), 281.

(19) L.M.Clarebrough, R. L. Segall and M.H. Loretto: Phil. Mag., 13(1966), 1285.

（20）例えば，吉田 銷：格子久陥之金属の機械的性質， 丸善, (1967), 112.

(21) P.B.Hirsch, A.Howie, R.B. Nicholson, D.W Pashley and M.J. Whelan: Electron Microscopy of Thin Crystals, Butterworths, London, (1965), 61.

(22) H.Hashimoto, A. Howie and M.J.Whelan : Proc. Roy. Soc. A, 269(1962), 80. 